\title{
KONTRIBUSI DAYA LEDAK OTOT TUNGKAI DAN KELENTUKAN TERHADAP TENDANGAN BELAKANG PADA PESILAT PADEPOKAN PENCAK SILAT BENGKULU \\ Yarmani \\ Universitas Bengkulu \\ Yarmani@unib.ac.id \\ Zulham Japriansyah \\ Universitas Bengkulu
}

\begin{abstract}
Abstrak
Penelitian ini bertujuan untuk mengetahui seberapa besar kontribusi daya ledak otot tungkai dan kelentukan terhadap kecepatan tendangan belakang pada pesilat padepokan pencak silat Bengkulu. Dalam penelitian ini mengunakan, metode korelasional. tes yang digunakan adalah tes daya ledak otot tungkai kelentukan pinggang, dan kecepatan tendangan. Populasi dalam peneitian berjumlah 25 orang, sedangkan sampel di tetapkan dengan teknik total sampling yaitu seluruh populasi 25 orang, sedangkan analisis data yang digunakan teknik analisis korelasi sederhana dan korelasi ganda dengan taraf signifikan $\alpha=$ 0,05 . Hasil analisis data menunjukkan bahwa 1) terdapat kontribusi yang berarti antara kontribusi daya ledak otot tungkai terhadap kecepatan tendangan belakang pesilat padepokan pencak silat Bengkulu sebesar $34,45 \%$ dengan perolehan $r_{\text {hitung }} 0,875>r_{\text {tab }} 0,396$. 2) terdapat kontribusi yang berarti antara kelentukan terhadap kecepatan tendangan belakang pesilat padepokan pencak silat Bengkulu sebesar $16,81 \%$ dengan peolehan $r_{\text {hitung }}$ $0,410>r_{\text {tab }} 0,396$. 3) terdapat kontribusi yang berarti antara daya ledak otot tungkai dan kelentukan secara bersama-sama terhadap kecepatan tendangan belakang pesilat padepokan pencak silat Bengkulu sebesar 36,24\% dengan perolahan $r_{\text {hitung }} 0,602>r_{\text {tab }} 0,347$.
\end{abstract}

\section{Kata Kunci: Daya Ledak, Kelentukan, Tendangan Belakang}

\begin{abstract}
This study aims to determine how much the contribution of explosive muscle leg power and flexibility to the speed of the back kick in Bengkulu martial arts martial arts fighters. In this study using a correlational method. the test used was a test of the leg muscle explosive strength of the waist, and the speed of the kick. The population in the study amounted to 25 people, while the sample was determined by the total sampling technique that is the entire population of 25 people, while the data analysis used was simple correlation analysis and multiple correlation with a significant level of $\alpha=0.05$. The results of data analysis showed that 1 ) there was a significant contribution between the contribution of limb muscle explosive power to the speed of the back kick of the martial arts pencak silat hermitage in the amount of $34.45 \%$ with the acquisition of $0.875>$ rtab 0.396. 2) there is a meaningful contribution between the flexibility to the speed of the back kick of the pencak silat hermitage paddle in Bengkulu of $16.81 \%$ with the acquisition of rhitung $0.410>$ rtab 0.396. 3) there is a significant contribution between the explosive power of the limb muscles and joint jointness to the speed of the back kick of the martial arts pencak silat hermitage in the amount of $36.24 \%$ with the process of calculating $0.602>$ rtab 0.347 .
\end{abstract}

Keywords: explosion power, flexsibelity, back kick 


\section{PENDAHULUAN}

Pencak silat adalah suatu seni bela diri tradisional yang berasal dari Indonesia. Seni bela diri ini secara luas dikenal di berbagai Negara Asia, Malaysia, Brunei, dan Singapura, Filipina selatan, dan Thailand selatan dan terutama di Indonesia, sesuai dengan penyebaran suku bangsa Melayu Nusantara. nama induk organisasi pencak silat di Indonesia adalah Ikatan Pencak Silat Indonesia (IPSI). Organisasi yang mewadahi federasifederasi pencak silat di berbagai negara adalah Persekutuan Pencak Silat Antara Bangsa (Persilat), yang dibentuk oleh Indonesia, Singapura, Malaysia dan Brunei Darussalam. Organisasi pencak silat di Indonesia di didirikan pada tanggal 18 Mei 1948 di Surakarta, yang diprakarsai oleh Mr. Wongsonegoro, yang saat itu menjabat sebagai ketua umum pertama IPSI (ikatan pencak silat indonesia).

Berdasarkan pedoman dan peraturan dalam berbagai pertandingan pencak silat bahwa ilmu bela diri pencak silat memiliki keunikan di bandingkan dengan olahraga bela diri lainnya, hal ini di tetapkan dalam empat pola dalam pertandingan pencak silat yaitu : 1) sikap pasang, 2) pola langkah, 3) serang bela, 4) kembali ke sikap pasang. Keempat pola tersebut merupakan satu kesatuan gerak yang membentuk suatu rangkaian sehingga menjadi pola gerak tertentu.

Seorang pesilat harus memiliki keterampilan tendangan yang cukup kuat dan akurat sehingga keterampilan tendangan tersebut di kategorikan sebagai keterampilan khusus. Oleh sebab itu tendangan yang baik adalah tendangan yang sulit untuk dibaca, atau di antisipasi, maupun ditangkap oleh lawan.
Teknik-teknik tendangan yang terdapat dalam pencak silat.menurut jenis tendangan yang sering dilakukan dalam pertandingan pencak silat kategori tanding terdiri dari tendangan depan, tendangan sabit, tendangan samping atau tendangan $\mathrm{T}$, dan tendangan belakang. Pada prinsipnya dapat dipergunakan untuk menyerang dalam pertandingan pencak silat, sebagaimana halnya dengan pukulan, tidak semua teknik tendangan dapat dipergunakan dalam pertandingan, berdasarkan efesiensi pelaksanaan teknik tendangan dan efektifitas untuk memperoleh angka serta keselamatan yang melakukan tendangan tersebut.

Selain di perguruan yang kita ketahui pada umumnya ada banyak sekali wadah dalam menampung atau tempat mempelajari pencak silat, salah satu nya adalah Padepokan pencak silat Bengkulu, padepokan ini adalah tempat pemusatan pesilat/atlet Bengkulu, yang di resmikan pada tanggal 27 desember 2018 dan mulai di operasikan awal tahun 2019, tempat ini di gunakan sebagai tempat para pesilat berlatih sehari-hari, di padepokan ini ada banyak pesilat dari berbagai perguruan serta Universitas yang ada di sekitaran kota Bengkulu seperti Universitas Bengkulu, Universitas Dehasen dan Institut agama islam negri kota Bengkulu, jumlah para pesilat yang ada di padepokan ini lebih kurang 35 orang yang aktif yang di dominasi oleh pesilat laki-laki yang berjumlah 25 orang dan sisanya nya adalah pesilat perempuan.

Berdasarkan pengamatan yang dilakukan peneliti pada pesilat padepokan pencak silat Bengkulu pada pelaksanaan latihan teknik dan tarung khususnya teknik tendangan belakang, para pesilat padepokan pencak silat Bengkulu mengatakan bahwa pada saat mereka melakukan tendangan 
belakang, tendangan mereka sering tertangkap meski tidak selalu terbanting oleh pihak lawan, tendangan mereka juga sering tidak tepat sasaran dan menurut pengakuan dari para pesilat mengatakan bahwa mereka sangat jarang melakukan latihan tendangan belakang, dalam latihan ini di duga para pesilat kurang memperhatikan pola kondisi fisik saat latihan kesemua nya menimbulkan dampak pada pesilat.

Dengan demikian, bahwa daya ledak otot tungkai dan kelentukan memiliki hubungan terhadap kualitas kemampuan tendangan belakang pesilat padepokan pencak silat Bengkulu untuk mencapai perporma terbaik dan tendangan yang baik saat latihan maupun pertandingan Universitas Bengkulu. Oleh karena itu penulis mengangkat masalah ini dengan melakukan penelitian yang berjudul "Kontribusi Daya Ledak Otot Tungkai Dan Kelentukan Terhadap Kecepatan Tendangan Belakang Pada Pesilat Padepokan Pencak Silat Bengkulu".

\section{METODE PENELITIAN}

Penelitian adalah suatu proses mencari tahu sesuatu secara sistematis dalam waktu yang relatif lama dengan menggunakan metode ilmiah serta aturanaturan yang berlaku. Menurut marzuki dalam badriah (2006:2) menyatakan bahwa : penelitian adalah kegiatan untuk memperoleh gambaran tentang suatu keadaan atau persoalalan dengan melakukan pengumpulan, pengolahan, penyajian, dan analisis data secara sistematis dan efisien untuk memecahkan suatu persoalan atau menguji hipotesi, jenis penelitian ini adaah penelitian kuantitatif.
Metode yang digunakan dalam penelitian ini adalah deskriptif korelasional dilanjutkan dengan mencari kontribusi dari masing-masing variabel bebas terhadap variabel terikat. Sesuai dengan judul penelitian ini untuk mengetahui seberapa besar kontribusi daya ledak otot tungkai dan kelentukan terhadap kecepatan tendangan Belakang pada pesilat padepokan pencak silat Bengkulu.

\section{HASIL DAN PEMBAHASAN}

Penelitian ini akan membahas mengenai hasil pengambilan data tes kekuatan otot tungkai dan kelentukan terhadap kecepatan tendangan belakang pesilat padepokan pencak silat Bengkulu, yang dilakukan di padepokan pencak silat Bengkulu, dengan jumlah sampel penelitian ini adalah 25 orang pesilat putra. Setelah melakukan pengambilan data penelitian, maka langkah awal untuk melakukan deskripsi variabel seperti yang dijelaskan pada bab sebelumnya bahwa didalam penelitian ini ada tiga variabel yang diteliti yakni kekuatan otot tungkai $\left(X_{1}\right)$ dan kelentukan $\left(X_{2}\right)$ sebagai variabel bebas dan kecepatan tendangan belakang sebagai variabel terikat (Y).

Setelah analisis data dilakukan terhadap hasil tes ketiga variabel Selanjutnya hasil dari penelitian kekuatan otot tungkai dan kelentukan (X) terhadap kecepatan tendangan belakang (Y) dijabarkan sebagai berikut:

\section{Hasil Tes daya ledak Otot tungkai $\left(X_{1}\right)$}

Berdasarkan hasil tes daya ledak otot tungkai, di peroleh skor maksimum adalah 2,76 dan skor min 1,94. Di samping itu di peroleh nilai mean (rata-rata) $=2,34$, median $=2,35$, modus $=1,99$ dan standar deviasi $=0,24$. Dengan demikian data berdistribusi normal, karena selisih nilai mean (rata-rata) dengan nilai median tidak lebih dari satu standar deviasi. disimpulkan bahwa dari 25 pesilat putra 
pada padepokan pencak silat Bengkulu sebanyak 7 orang pesilat(28\%) memiliki kategori nilai baik 2,54-2,,79 m dan 12 pesilat $(48 \%)$ memiliki kategori cukup nilai 2,20-2,53 $\mathrm{m}$ dan sebanyak 6 orang siswa (24\%) memiliki kategori nilai kurang 1,902,19 sedangkan untuk kategori baik sekali dan kurang sekali tidak dimiliki (0\%)

\section{Hasil tes kelentukan $\left(\mathrm{X}_{2}\right)$}

Dari Berdasarkan hasil tes daya ledak otot tungkai, di peroleh skor maksimum adalah 11,90 dan skor min 4,5. Di samping itu di peroleh nilai mean (rata-rata) $=9,22$ , median $=9,4$, modus $=6,8$ dan standar deviasi $=2,1$. Dengan demikian data berdistribusi normal, karena selisih nilai mean (rata-rata) dengan nilai median tidak lebih dari satu standar deviasi. disimpulkan bahwa dari 25 pesilat putra pada padepokan pencak silat Bengkulu sebanyak 3 orang pesilat (12\%) memiliki kategori nilai $11,5-19 \mathrm{~cm}$ tergolong kategori baik dan 22 pesilat (88\%) memiliki kategori nilai -1,5-11,4 cm tergolong kategori cukup, sedangkan untuk kategori baik sekali, kurang dan kurang sekali tidak dimiliki (0\%) .

Dari Dari Berdasarkan hasil tes trndangan belakang pencak silat, di peroleh skor maksimum = 15 dan skor $\min$ 9 Di samping itu di peroleh nilai mean (rata-rata $)=12,64$, median $=13$, modus $=$ 14 dan standar deviasi $=2.05$. Dengan demikian data berdistribusi normal, karena selisih nilai mean (rata-rata) dengan nilai median tidak lebih dari satu standar deviasi. disimpulkan bahwa dari 25 pesilat putra pada padepokan pencak silat Bengkulu sebanyak 12 orang pesilat(48\%) memiliki kategori nilai $13,8-15$ dan 4 pesilat (16\%) memiliki kategori nilai 12,513,7 dan sebanyak 4 pesilat (16\%) memiliki kategori nilai 9,9-11,1 dan sebanyak 5 pesilat (20\%) memiliki katergori nilai 8,69,8 sedangkan kategori nilai 9,9-11,1 tidak dimiliki (0\%) . Analisis Data
Sebelum melakukan pengujian terhadap hipotesis yang diajukan dalam penelitian ini, maka terlebih dahulu dilakukan uji persyaratan analisis data, yaitu uji normalitas data dan uji homogenitas varians.

a. Uji Homogenitas

Pengujian homogenitas data di lakkukan dengan mencari standar deviasi variabel dan dengan menggunakan rumus uji $F$, unutk mencari data yang di uji berdistibusi Homogen atau tidak, hasil tes homogenitas daya ledak otot tungkai $\left(X_{1}\right)$ Kelentukan $\left(\mathrm{X}_{2}\right)$ dan kecepatan tendangan belakang $(\mathrm{Y})$ pada pesilat padepokan pencak silat Bengkulu.

hasil pengujian homogenitas varians data $X$ dan $Y$, diamana di dapat kan hasil untuk variabel daya ledak otot tungkai $X_{1}$, $F_{\text {hitung }}=0,281$ sedangkan nilai $F_{\text {tabel }}$ pada taraf signifiknasi 0,05 dengan $\mathrm{dk}=(\mathrm{b}) \cdot(\mathrm{n}-1)$ $=(1) \cdot(25-1)=1,24$ dimana 1 sebagai pembilang dan 24 sebagai peyebut adalah sebesar 4,26. $F_{\text {hitung }}<F_{\text {tabel }}$ yaitu $0,281<$ 4,26 (Homogen). Kemudian di dapat hasil pengujian homogenitas kelentukan $X_{2}$ Dari perhitungan di atas di dapat Dari perhitungan di atas di dapat nilai $F_{\text {hitung }}$ $=0,281$ sedangkan nilai $F_{\text {tabel }}$ pada taraf signifiknasi 0,05 dengan $d k=(b) .(n-1)=$ $(1) \cdot(25-1)=1,24$ dimana 1 sebagai pembilang dan 24 sebagai peyebut adalah sebesar 4,26. $F_{\text {hitung }}<F_{\text {tabel }}$ yaitu $1,207<$ 4,26 (Homogen).

\section{PENUTUP}

\section{Simpulan}

Berdasarkan penelitian dan pembahasan yang telah dilakukan pada pesilat putra padepokan pencak silat Bengkulu maka dapat ditarik kesimpulan :

1. Terdapat hubungan yang berarti antara daya ledak otot tungkai terhadap kecepatan tendangan belakang pesilat padepokan pencak silat Bengkulu, dengan peroehan $r_{\text {hitung }} 0,587>r_{\text {tab }} 0,396$. Besarnya 
kontribusi daya ledak otot tungkai terhadap kecepatan tendangan belakang pesilat yaitu sebesar $34,45 \%$.

2. Terdapat hubungan yang berarti antara kelentukan terhadap kecepatan tendangan belakang pesilat Padepokan Pencak Silat Bengkulu, dengan perolehan $r$ hitung 0,410> $r$ tabel 0,396. Besarnya kontribusi kelentukan terhadap kecepatan tendangan belakang pesilat sebesar $16,81 \%$.

3. Terdapat hubungan yang berarti antara daya ledak otot tungkai dan kelentukan secara bersama-sama kecepatan tendangan belakang pesilat Padepokan Pencak Silat Bengkulu dengan perolehan rhitung 0,602 > $r_{\text {tabel }} 0,347$. Besarnya kontribusi antara daya ledak otot tungkai dan kelentukan terhadap kecepatan tendangan belakang pesilat yaitu sebesar $36,24 \%$.

\section{Saran-saran}

Berdasarkan pada kesimpulan diatas, maka penulis dapat memberikan saran-saran yang dapat membantu mengatasi masalah yang ditemui dalam menghasilkan kecepatan tendangan belakang pesilat Padepokan Pencak Silat Bengkulu, yaitu

1. Bagi pelatih pada umumnya dan khususnya pelatih Padepokan Pencak Silat Bengkulu disarankan untuk melatih unsur daya ledak otot tungkai dan kelentukan dengan cara melatih otot-otot yang dominan dalam menghasilkan kecepatan tendangan belakang.

2. Bagi pesilat Padepokan Pencak Silat Bengkulu dapat meningkatkan kecepatan tendangan belakang dengan cara melakukan latihan secara sistematis dan berkesinambungan.

3. Bagi peneliti yang ingin melanjutkan penelitian ini agar dapat menjadikan penelitian ini sebagai bahan informasi dan meneliti dengan jumlah populasi atau sampel yang lebih besar serta di daerah yang berbeda.

4.

\section{DAFTAR PUSTAKA}

Harsono. Coaching dan aspek-aspek psikologi dalam coaching. Jakarta : departemen pendidikan dan kebudayaan direktorat pendidikan tinggi, 2014.

Iskandar, Metodologi Penelitian pendidikan dan Sosial (Kualitatif Dan Kuantitatif),Jakarta:Gaung Persada Press, 2010

Johansyah, Hendro, Pencak Silat, Jakarta: PT. Raja Grafindo Persada, 2014.

Lubis, Johansyah, Berbagai Perguruan Silat di Indonesia, Jakarta: PT.Raja Grafindo Persada, 2004.

Nabillah, Azri Ayu. 2015. Skripsi: Kontribusi Keseimbangan dan Kelentukan serta Daya Ledak Otot Tungkai terhadap Performa Kata pada Mahasiswa UKM Karate STKIP Dharma Wacana Metro. Lampung: Universitas Lampung.

Nandika, Febri. 2015. Skripsi: Hubungan antara Daya Ledak dan Kekuatan Otot Tungkai dengan Hasil Tendangan dalam Bermain Sepakbola pada Siswa Putra Kelas XI SMK Muhammadiyah 1 Terbanggi Besar Lampung Tengah. Lampung: Universitas Lampung.

Rafael. 2015. Skripsi: Kontribusi Daya Ledak Otot Tungkai Dan Kelentukan Terhadap Kemampuan Shooting Sepakbola Siswa SMA Negri 1 Lebong Tengah. Padang: Universitas Negri Padang.

R. Lumintuarso, 2001. Pemandu Bakat Atle tik. Pada www.lahandata.blogspot.c om yang diunggah pada Rabu 15 Februari 2018

Riduwan. 2005. Prosedur Penelitian. Jakarta: PT Rineka Cipta. 